\title{
Variation in physical characteristics of rainfall in Iran, determined using daily rainfall concentration index and monthly rainfall percentage index
}

\author{
Sadegh Kaboli ${ }^{1}$ Ali Akbar Hekmatzadeh ${ }^{1} \cdot$ Hamid Darabi $^{2}$ (D) Ali Torabi Haghighi $^{2}$ \\ Received: 10 October 2020 / Accepted: 1 February 2021 / Published online: 17 February 2021 \\ (C) The Author(s) 2021
}

\begin{abstract}
Variations in rainfall characteristics play a key role in available water resources for a country. In this study, spatial and temporal variations in rainfall in Iran were determined using the daily rainfall concentration index (DRCI) and monthly rainfall percentage index (MRPI), based on 30-year (1987-2016) daily precipitation records from 80 meteorological stations throughout Iran. The results showed that MRPI differed between locations within Iran, with increasing or decreasing trends observed in different areas. The highest significant decreasing trend in MRPI (3-7\% per decade) was found for March rainfall in western Iran, and the highest increasing trend in MRPI (3-7\% per decade) for November rainfall in eastern and southern Iran. The DRCI values obtained varied from 0.57 to 0.71 , indicating moderate and high rainfall concentrations, with the highest DRCI values in coastal zones of Iran near the Caspian Sea and the Persian Gulf. Trend analysis showed increasing trends in DRCI values at $80 \%$ of meteorological stations, and these trends were significant at $37 \%$ of those stations.
\end{abstract}

\section{Introduction}

Knowledge of spatio-temporal variations in rainfall is crucial for water resources management, water infrastructure design, forecasting droughts and floods, and providing water for agricultural activities (Darand and Khandu 2020; Peng et al. 2014; Pulwarty et al. 2010; Sarricolea et al. 2019; Vyshkvarkova et al. 2018). In recent decades, the spatial and temporal distribution of rainfall in different regions of the world has been investigated in many studies, some of which indicate an influence of global warming on rainfall pattern (Alijanian et al. 2019; Cochrane et al. 2020; Fadhel et al. 2018; Khalili et al. 2016; Khavarian-Garmsir et al. 2019; Rademacher-Schulz et al. 2014; Haghighi et al. 2020; Singh and Qin 2020).

In terms of watershed management, changes in rainfall patterns affect soil erosion and sediment yield at the watershed scale (Alavinia et al. 2019; Narayana 2006; Vyshkvarkova

Hamid Darabi

hamid.darabi@oulu.fi

1 Department of Civil and Environmental Engineering, Shiraz University of Technology, Po. Box 71555-313, Shiraz, Iran

2 Water, Energy and Environmental Engineering Research Unit, University of Oulu, PO Box 4300, F IN-90014 Oulu, Finland et al. 2018; Zhao et al. 2012; Pirnia et al. 2019a). In addition, temporal changes in rainfall pattern may severely influence people's livelihoods, especially in warm, dry areas where livelihoods are based on cropping (Abou Zaki et al. 2018; Cochrane et al. 2020; Henry et al. 2004; Pérez-Gutiérrez et al. 2020; Saino et al. 2007; Spekkers et al. 2013; Sun et al. 2019; Torabi Haghighi et al. 2020). Therefore, it is important to analyze rainfall variations at temporal and spatial scales for sustainable water resources management and for the prevention of severe floods or droughts (Singh et al. 2020; Singh and Qin 2020; Strauch et al. 2015; Xu et al. 2010; Hekmatzadeh et al. 2020).

Several studies have examined rainfall patterns in Iran. For instance, Alijani et al. (2008) calculated the daily rainfall concentration index (DRCI), using meteorological records for 1982-2004 from 90 meteorological stations located across the country and concluded that rainfall in coastal regions near the Persian Gulf and the Caspian Sea occurs mainly on a few rainy days. Tabari and Talaee (2011) studied annual and seasonal precipitation trends at 41 stations throughout Iran for the period 1966-2005 and identified a decreasing trend in annual precipitation at around $60 \%$ of the stations. Different spatial and temporal rainfall patterns in every season in Iran were observed by Javari (2017), based on records from synoptic stations. Rahimi and Fatemi (2019) calculated eight extreme precipitation indices, including Rx1day and R20, in 
different areas of Iran using records from 33 synoptic stations, and observed significant increasing trends in the indices from 1960 to 2017. Bahrami et al. (2019) computed standardized precipitation index (SPI) for 38 Iranian synoptic stations using data from 1967 to 2014 and found that SPI values at $84 \%$ of these stations displayed negative trends.

All the above-mentioned studies used precipitation records from meteorological stations. Recently, several studies have investigated precipitation patterns in Iran using satellite-based data (Akbari et al. 2019; Alijanian et al. 2019; Katiraie-Boroujerdy et al. 2013). For example, Alijanian et al. (2019) computed SPI values for Iran using PERSIANN-CDR and MSWEP data.

Many studies have employed DRCI as a key indicator for determining daily rainfall heterogeneity and extreme events (Benhamrouche et al. 2015; Deng et al. 2018; Espinoza and Martín-Vide 2014; Llano 2018; Martin-Vide 2004; Monjo and Martin-Vide 2016; Royé and Martin-Vide 2017). High DRCI values can indicate the probability of floods and droughts, so understanding spatio-temporal alterations in DRCI values can help decision-makers in integrated water resource management. Due to climate change in recent decades, it is of critical importance to determine the spatial and temporal variability in DRCI using up-to-date precipitation records.

To our knowledge, little attention has been paid to date to temporal trends in yearly DRCI values in Iran. Moreover, numerous dams have been constructed in Iran during the past century, for water storage and flood control, operating under specified rule curves. Due to possible spatial and temporal changes in precipitation, these rule curves may need modification, creating a need for ongoing studies in the country. In this study, DRCI and monthly rainfall percentage index (MRPI) were used to examine the current rainfall pattern in Iran and changes during the past three decades. To our knowledge, spatial and temporal trends in MRPI have not been studied previously in Iran.

The main objective of this study was to determine spatiotemporal variations in DRCI and MRPI throughout Iran, using records from 80 meteorological stations covering the period 1987-2016. Temporal changes in DRCI and MRPI were examined by applying the Mann-Kendall test to the values calculated for each year in the study period. Spatial variations in DRCI and MRPI were determined using the inverse distance weighting (IDW) estimator applied to 30 years of daily data. The relationship between MRCI or DRCI and elevation was assessed for all stations using Spearman's correlation test.

\section{Materials and methods}

\subsection{Study area}

Iran occupies a total area of $1,648,000 \mathrm{~km}^{2}$ and is located in the Middle East $\left(44-64^{\circ} \mathrm{E} ; 25-40^{\circ} \mathrm{N}\right)$. It is bordered by the
Persian Gulf and the Oman Sea to the south and the Caspian Sea to the north. The topography of Iran is diverse, including the Zagros mountains (3500 m above mean sea level (msl)) and the Alborz mountains ( $5500 \mathrm{~m}$ above $\mathrm{msl}$ ) at the northern and western borders, respectively, and two vast deserts with a mean elevation of $600 \mathrm{~m}$ above msl in central and eastern areas. The mean annual rainfall in Iran is around $250 \mathrm{~mm}$, but ranges from less than $100 \mathrm{~mm}$ in the east to more than $2000 \mathrm{~mm}$ in the north, resulting in various climates in Iran. In general, Iran is classified as dry and semi-arid, with low rainfall and high evapotranspiration (Khalili et al. 2016; Saghebian et al. 2014).

For the present analysis, available daily precipitation datasets from 80 meteorological stations in different regions of Iran that have daily records from 1987 to 2016 were used (obtained from Iran Meteorological Organization (IMO)). The locations of the stations are shown in Fig. 1 and the following variables are presented for each station in Table 1; Mean annual rainfall $(\mathrm{mm})$, mean annual rainy days $(\mathrm{N})$, coefficient of variation in annual rainfall (CV (\%)), and elevation (m) at every station. The elevation of the stations varied between $26 \mathrm{~m}$ below msl (Bandar-Anzali station) and $2465 \mathrm{~m}$ above msl (Abali station). The spatial distribution of annual rainfall in Iran is shown in Fig. 2.

\subsection{Daily rainfall concentration index}

The daily rainfall concentration index was first developed by Martin-Vide (2004) and measures the irregularity of rainfall distribution. It is computed by determining the relationship between rainfall cumulative percentage and cumulative frequency of rainy days, using daily records. In the first step, precipitation data are classified into 1-mm intervals, starting with $0.1-0.9 \mathrm{~mm}, 1-1.9$ $\mathrm{mm}$, etc., up to the highest recorded value (Royé and MartinVide 2017; Serrano-Notivoli et al. 2018). The number of days with each category of rainfall value is then determined. In the next step, the relative cumulative frequency of rainy days $(X \mathbf{i})$, expressed as a percentage of the total number of rainy days, and the cumulative percentage of rainfall records $\left(Y_{i}\right)$ is defined according to Eqs. 1 and 2, respectively:

$X_{i}=100 \times \frac{\sum_{j=1}^{\mathrm{i}} n_{i}}{\sum_{j=1}^{\mathrm{N}} \mathrm{n}_{\mathrm{i}}}$
$\mathrm{Y}_{\mathrm{i}}=100 \times \frac{\sum_{\mathrm{j}=1}^{\mathrm{i}} \mathrm{P}_{\mathrm{i}}}{\sum_{\mathrm{j}=1}^{\mathrm{N}} \mathrm{P}_{\mathrm{i}}}$

where $n_{\mathrm{i}}$ is the number of rainy days and $P_{\mathrm{i}}$ is the amount of rainfall for class $i$, and $N$ is the number of non-zero groups.

Next, it is assumed that $X_{\mathrm{i}}$ and $Y_{\mathrm{i}}$ are related by an exponential relationship according to Eq. 3 (Rahman and Islam 2019; Royé and Martin-Vide 2017): 


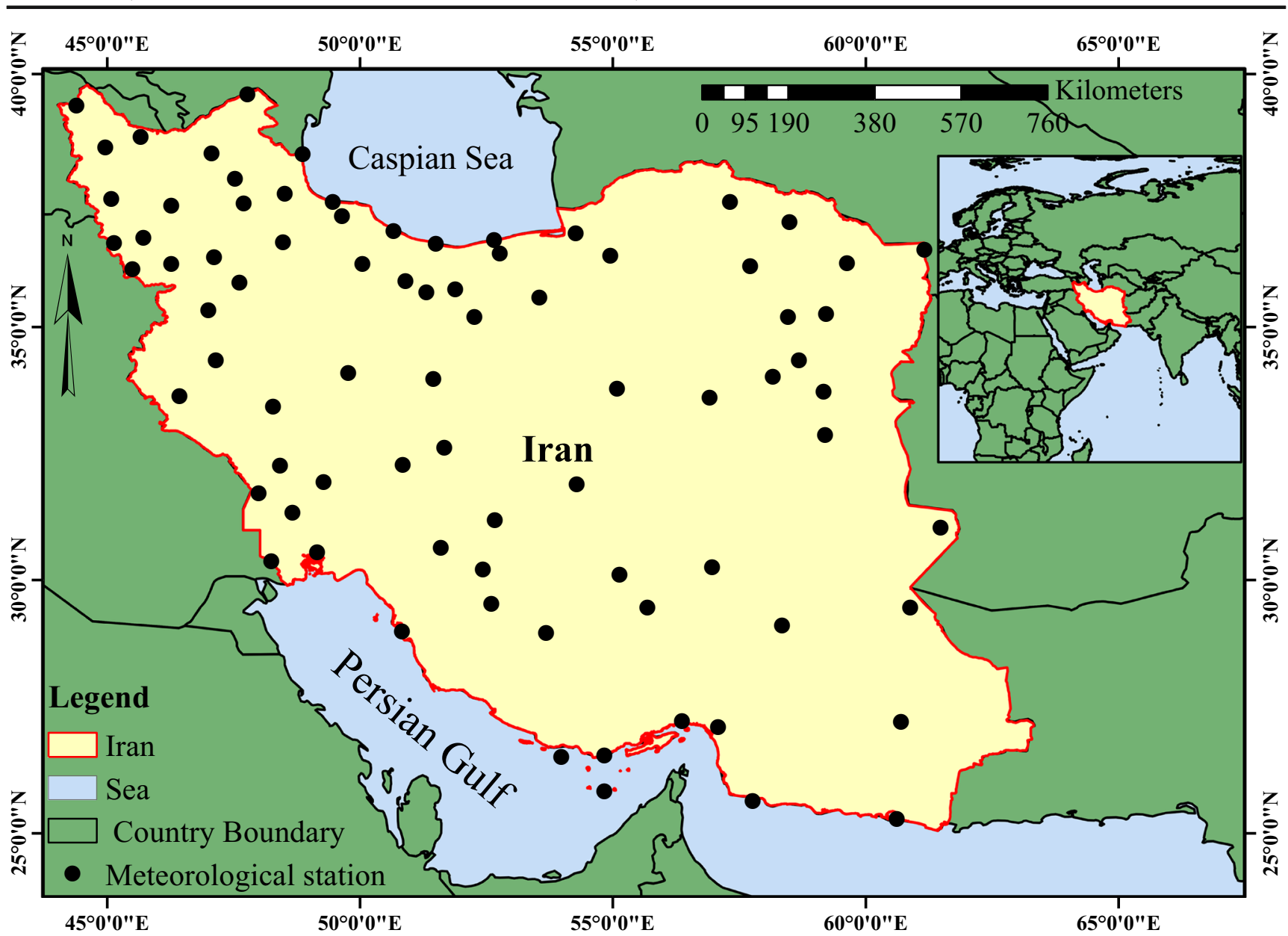

Fig. 1 Geographic location of Iran and the spatial locations of the meteorological stations

$\mathrm{Y}=\mathrm{aXexp}(\mathrm{bX})$

where $a$ and $b$ are constants that can be estimated using the least-squares technique.

Finally, DRCI is defined as:

$$
D R C I=\mathrm{S} / 5000
$$

where $S$ is the area between the exponential curve and the line $Y=X$, estimated according to Eq. 5 (Rahman and Islam 2019):

$s=\int_{0}^{100}[X-a \operatorname{Xexp}(b X)] d X$

The value of the DRCI varies from 0 to 1 , with higher values of DRCI indicating that a few rainy days account for the total amount of rainfall. As mentioned in previous studies, DRCI $>0.61$ can be considered high, $0.55<$ DRCI $<0.61$ moderate, and DRCI $<0.55$ low (REFs).

\subsection{Monthly rainfall percentage index}

In order to identify possible shifts in rainfall, the contribution of rainy months to annual rainfall is calculated as:
$\mathrm{MRPI}_{\mathrm{i}}=\left(P_{i} / P_{\text {tot }}\right) \times 100$

where $\mathrm{MRPI}_{i}$ is the contribution of the month $i$ to annual rainfall (\%), $P_{i}$ is the amount of rainfall in a month $i(\mathrm{~mm})$, and $P_{\text {tot }}$ is the total annual rainfall (mm).

\subsection{Trend analysis using the Mann-Kendall test}

Non-parametric trend tests are employed extensively to detect trends in time series (Ahn and Palmer 2016; Güçlü 2020; Hamed 2008; Pirnia et al. 2019b). The Mann-Kendall (MK) test is one of the most widely used methods for identifying significant and non-significant trends in climate variables (Datta and Das 2019; Moradi 2020; Pirnia et al. 2019b). The presence of a significant trend is assessed with the $Z$ value, where a positive value of $Z$ indicates an upward trend, while a negative $Z$ value signifies a downward trend.

The null hypothesis of no significant trend is accepted if $-Z_{1-\alpha}$ ${ }_{2}<Z<Z_{1-\alpha / 2}$, where $\alpha$ is the significance level. In this study, significance levels of $10 \%$ and $5 \%$ were considered. To measure the magnitude of trends, the Theil-Sen slope estimator was employed (Sayemuzzaman and Jha 2014; Sen 1968; Theil 1992). 
Table 1 Characteristics of the 80 meteorological stations from which data were obtained for the present study

\begin{tabular}{|c|c|c|c|c|c|c|}
\hline Station & Latitude, E & Longitude, $\mathrm{N}$ & Elevation (m above msl) & Precipitation (mm) & $N$ & $\mathrm{CV}(\%)$ \\
\hline Abadan & 30.37 & 48.25 & 6.6 & 151.44 & 32.33 & 15.36 \\
\hline Abadeh & 31.18 & 52.67 & 2030 & 96.98 & 44.37 & 17.44 \\
\hline Abali & 35.75 & 51.88 & 2465.2 & 501.09 & 104.7 & 33.49 \\
\hline Abumusa & 25.83 & 54.83 & 6.6 & 89.69 & 17.1 & 11.51 \\
\hline Ahar & 38.43 & 47.07 & 1390.5 & 258.05 & 108.9 & 31.33 \\
\hline Ahvaz & 31.33 & 48.67 & 22.5 & 216.01 & 47.67 & 17.27 \\
\hline Arak & 34.1 & 49.77 & 1708 & 297.68 & 72.63 & 24.36 \\
\hline Astara & 38.42 & 48.87 & -18 & 1198.12 & 149.23 & 35.58 \\
\hline Babolsar & 36.72 & 52.65 & -21 & 927.5 & 110.93 & 28.57 \\
\hline Bamok & 29.1 & 58.35 & 1066.9 & 55.33 & 18.43 & 12.2 \\
\hline Bandar-Abasok & 27.22 & 56.37 & 9.8 & 169.23 & 24.7 & 11.6 \\
\hline Bandar-Anzali & 37.47 & 49.47 & -26 & 1735.07 & 153.43 & 35.24 \\
\hline Bandar-Lengeh & 26.53 & 54.83 & 22.7 & 125.21 & 18.2 & 11.27 \\
\hline Bandar- Mahshahr & 30.55 & 49.15 & 3 & 150.13 & 38.07 & 17.57 \\
\hline Bijar & 35.88 & 47.62 & 1883.4 & 306.72 & 93.47 & 28.86 \\
\hline Birjand & 32.87 & 59.2 & 1491 & 151.89 & 49.13 & 20.33 \\
\hline Bojnurd & 37.47 & 57.32 & 1091 & 217.3 & 90.57 & 29.3 \\
\hline Bostan & 31.72 & 48 & 7.8 & 146.42 & 34.27 & 18.1 \\
\hline Bushehr & 28.98 & 50.83 & 19.6 & 263.14 & 44.17 & 15.65 \\
\hline Chabahar & 25.28 & 60.62 & 8 & 61.6 & 12.07 & 10.26 \\
\hline Dorudzan & 30.22 & 52.43 & 2025 & 403.24 & 45.13 & 21.7 \\
\hline Esfahan & 32.62 & 51.67 & 1550.4 & 128.91 & 39.47 & 17.29 \\
\hline Fasa & 28.97 & 53.68 & 1288.3 & 268.33 & 33.47 & 16.74 \\
\hline Ferdows & 34.02 & 58.17 & 1293 & 102.76 & 41.03 & 20.55 \\
\hline Garmsar & 35.2 & 52.27 & 825.2 & 90.4 & 38.7 & 18.61 \\
\hline Gharakhil & 36.45 & 52.77 & 14.7 & 621.5 & 126.33 & 33.62 \\
\hline Gonabad & 34.35 & 58.68 & 1056 & 107.94 & 44 & 20.17 \\
\hline Gorgan & 36.85 & 54.27 & 13.3 & 522.43 & 110.03 & 28.83 \\
\hline Ilam & 33.63 & 46.43 & 1337 & 483.37 & 70.43 & 27.31 \\
\hline Iranshahr & 27.2 & 60.7 & 591.1 & 104.4 & 24.67 & 13.07 \\
\hline Jask & 25.63 & 57.77 & 5.2 & 77.15 & 15.17 & 10.66 \\
\hline Jolfa & 38.75 & 45.67 & 736.2 & 180.85 & 84.3 & 27.99 \\
\hline Karaj & 35.92 & 50.9 & 1312.5 & 217.84 & 72.93 & 27.7 \\
\hline Kashan & 33.98 & 51.45 & 982.3 & 128.02 & 40.03 & 19.12 \\
\hline Kashmar & 35.2 & 58.47 & 1109.7 & 155.97 & 49.9 & 21.7 \\
\hline Kerman & 30.25 & 56.97 & 1753.8 & 126.4 & 39.2 & 18.62 \\
\hline Kermanshah & 34.35 & 47.15 & 1318.6 & 417.96 & 79.6 & 26.24 \\
\hline Khalkhal & 37.63 & 48.52 & 1796 & 329.84 & 99.97 & 33.74 \\
\hline Khoramabad & 33.43 & 48.28 & 1147.8 & 476.38 & 74.77 & 25.81 \\
\hline Khoy & 38.55 & 44.97 & 1103 & 262.73 & 94.03 & 27.18 \\
\hline Khur-Va-Biabanak & 33.78 & 55.08 & 845 & 54.61 & 33.57 & 15.91 \\
\hline Kish & 26.5 & 53.98 & 30 & 105.06 & 21.93 & 13.49 \\
\hline Mahabad & 36.77 & 45.72 & 1385 & 347.09 & 78.87 & 29.53 \\
\hline Maku & 39.38 & 44.39 & 1411.3 & 265.69 & 122.73 & 34.41 \\
\hline Maragheh & 37.4 & 46.27 & 1477.7 & 249.07 & 81.93 & 28.2 \\
\hline Mashhadok & 36.27 & 59.63 & 999.2 & 240.94 & 79.23 & 24.53 \\
\hline Masjedsoleyman & 31.93 & 49.28 & 320.5 & 352.55 & 50.27 & 21.59 \\
\hline Mianeh & 37.45 & 47.7 & 1110 & 240.56 & 81.4 & 29.21 \\
\hline Minab & 27.1 & 57.08 & 29.6 & 148.54 & 21.8 & 13.88 \\
\hline
\end{tabular}


Table 1 (continued)

\begin{tabular}{|c|c|c|c|c|c|c|}
\hline Station & Latitude, E & Longitude, $\mathrm{N}$ & Elevation (m above $\mathrm{msl}$ ) & Precipitation (mm) & $N$ & $\mathrm{CV}(\%)$ \\
\hline Nowshahr & 36.65 & 51.5 & -20.9 & 1192.44 & 135.47 & 31.9 \\
\hline Orumiyeh & 37.53 & 45.08 & 1315.9 & 308.2 & 89.5 & 25.08 \\
\hline Parsabad & 39.6 & 47.78 & 31.9 & 229.47 & 77.27 & 27.35 \\
\hline Piranshahr & 36.67 & 45.13 & 1455 & 613.49 & 86.1 & 30.66 \\
\hline Qaen & 33.72 & 59.17 & 1432 & 133.18 & 52.83 & 21.36 \\
\hline Qazvin & 36.25 & 50.05 & 1279.2 & 316.88 & 90.17 & 27.5 \\
\hline Quchan & 37.07 & 58.5 & 1287 & 279.41 & 83.37 & 29.11 \\
\hline Ramsar & 36.9 & 50.67 & -20 & 1234.42 & 136.17 & 25.42 \\
\hline Rasht & 37.2 & 49.65 & 36.7 & 1333.52 & 146.37 & 34.8 \\
\hline Sabzevar & 36.2 & 57.72 & 977.6 & 186.78 & 58.97 & 22.38 \\
\hline Safiabad & 32.27 & 48.42 & 82.9 & 254.26 & 51.93 & 20.54 \\
\hline Saghez & 36.25 & 46.27 & 1522.8 & 449.98 & 84.2 & 28.2 \\
\hline Sanandaj & 35.33 & 47 & 1373.4 & 386.01 & 85.23 & 26.66 \\
\hline Sarab & 37.93 & 47.53 & 1682 & 210.82 & 101.5 & 30.88 \\
\hline Sarakhs & 36.53 & 61.17 & 235 & 165.89 & 54.3 & 23.47 \\
\hline Sardasht & 36.15 & 45.5 & 1670 & 766.14 & 93.6 & 31.87 \\
\hline Semnan & 35.58 & 53.55 & 1130.8 & 137.45 & 48.9 & 19.35 \\
\hline Shahrebabak & 30.1 & 55.13 & 1834.1 & 116.96 & 28.67 & 17.54 \\
\hline Shahrekord & 32.28 & 50.85 & 2048.9 & 326.57 & 62.8 & 22.47 \\
\hline Shahrood & 36.42 & 54.95 & 1345.3 & 153.31 & 58.83 & 20.31 \\
\hline Shiraz & 29.53 & 52.6 & 1484 & 317.09 & 49.23 & 19.96 \\
\hline Sirjan & 29.47 & 55.68 & 1739.4 & 107.07 & 26.87 & 16.23 \\
\hline Tabas & 33.6 & 56.92 & 711 & 62.21 & 35.37 & 17.39 \\
\hline Takab & 36.38 & 47.12 & 1765 & 287.71 & 95.53 & 29.83 \\
\hline Tehran & 35.68 & 51.32 & 1190.8 & 232.71 & 78.67 & 24.23 \\
\hline Torbate heydarie & 35.27 & 59.22 & 1450.8 & 253.92 & 62.77 & 23.27 \\
\hline Yasuj & 30.63 & 51.6 & 1831.5 & 671.84 & 63.33 & 25.77 \\
\hline Yazd & 31.9 & 54.28 & 1237.2 & 51.12 & 31.87 & 14.12 \\
\hline Zabol & 31.03 & 61.48 & 489.2 & 53.34 & 22.43 & 12.56 \\
\hline Zahedan & 29.47 & 60.88 & 1370 & 75.45 & 32.53 & 13.73 \\
\hline Zanjan & 36.68 & 48.48 & 1663 & 289.21 & 103.57 & 28.69 \\
\hline
\end{tabular}

Since the presence of positive or negative autocorrelation in the data may lead to overestimation or underestimation of positive or negative trends, the time series should be serially independent. In this study, the trend-free pre-whitening (TFPW) method was used to remove possible autocorrelation in the data (Yue and Hashino 2003; Yue et al. 2002).

\subsection{Interpolation method}

To determine the spatial distribution of DRCI and MRPI, the inverse distance weighting (IDW) method was applied. This technique has been widely employed for determining the spatial distribution of meteorological parameters (Caloiero et al. 2020; Chen and Liu 2012; Noori et al. 2014). The ArcGIS 10.5 software was used to produce zoning maps for Iran.

\subsection{Spearman correlation}

The non-parametric Spearman correlation method is widely used to measure the correlation between climate variables (Zhang et al. 2016). The value of Spearman's correlation coefficient $(r)$ ranges between $-1 \leq r \leq 1$, where the closer $r$ is to +-1 , the stronger the monotonic relationship.

\section{Results and discussion}

\subsection{Spatial distribution of DRCI}

Daily rainfall concentration curves for the 80 meteorological stations were created using all available data from 1987 to 


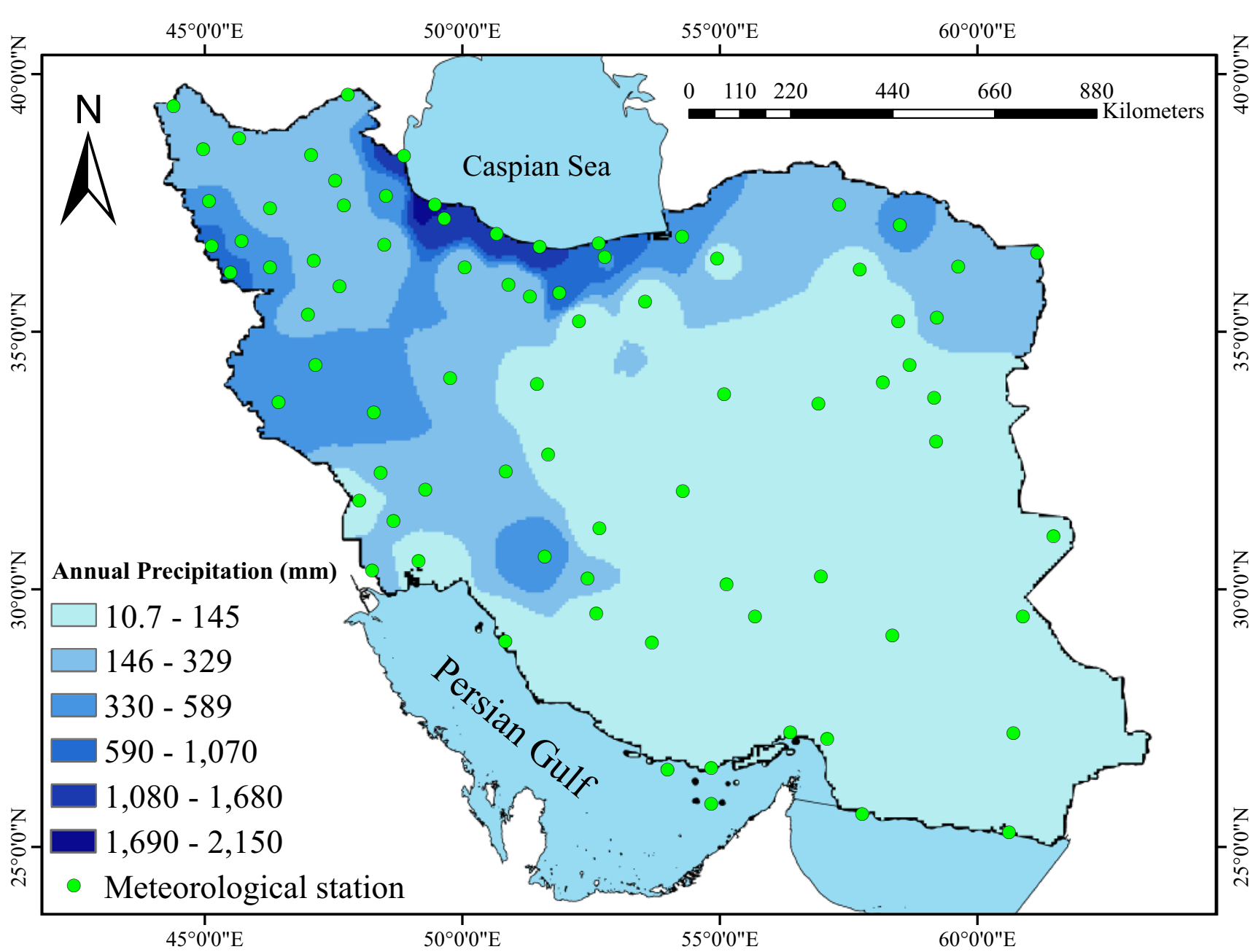

Fig. 2 Spatial distribution of annual rainfall in Iran during 1987-2016

2016. The DRCI values obtained varied from 0.57 at Shahrebabak station to 0.72 at Bandar Abbas station, i.e., a difference of 0.15 across Iran (Fig. 3). The DRCI values indicated a moderate or high level of rainfall concentration in Iran, since the value exceeded 0.57 at all stations (Fig. 4). As shown in Fig. 4b, more than $66 \%$ of rain events occurred on only $25 \%$ of rainy days in Iran in the study period. These results reveal irregular precipitation in Iran, with some heavy rainfall events. Hence, the possibility of flooding is high, especially in areas with relatively low annual rainfall. A previous study by Alijani et al. (2008) calculated DRCI values for Iran using precipitation data from 1982 to 2004 and obtained values ranging from 0.59 to 0.73 , which is similar to the range obtained in this study using data from 1987 to 2016.

As indicated in Fig. 4, DRCI in the majority of Iran is higher than 0.61 , indicating the possibility of extreme rain events. Iran's coastlines, located to both the north and south, were found to have the highest DRCI values, i.e., showed the greatest anomalies in daily rainfall. Some stations, such as Bandar Abbas and Bushehr in the south and Anzali in the north (coastal zones), had DRCI values of over 0.7 , which means that about $80 \%$ of rainfall occurs on only $25 \%$ of the rainy days in a year (Fig. 4b). It should be pointed out that rainfall in

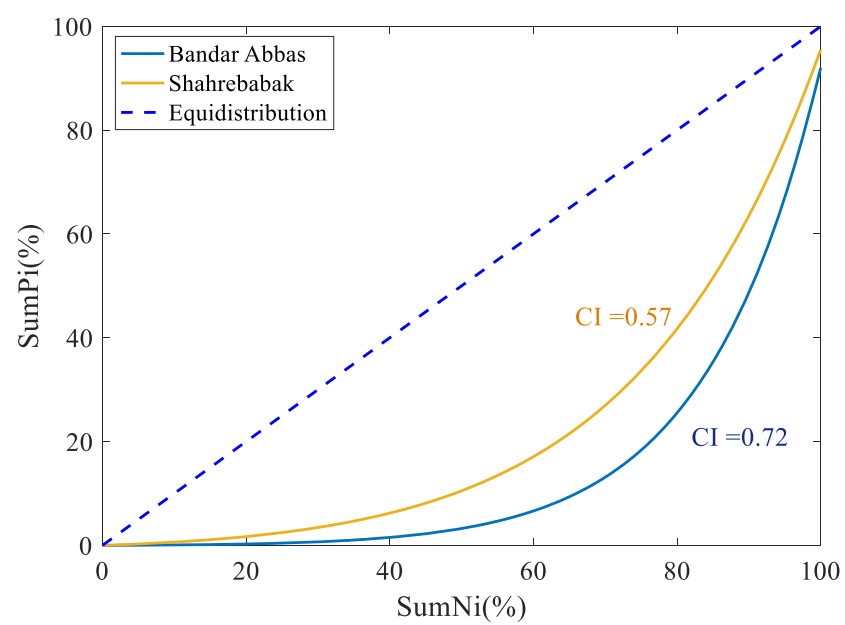

Fig. 3 Exponential curves and daily rainfall concentration index (DRCI) values at the meteorological stations Shahrebabak and Bandar Abbas 


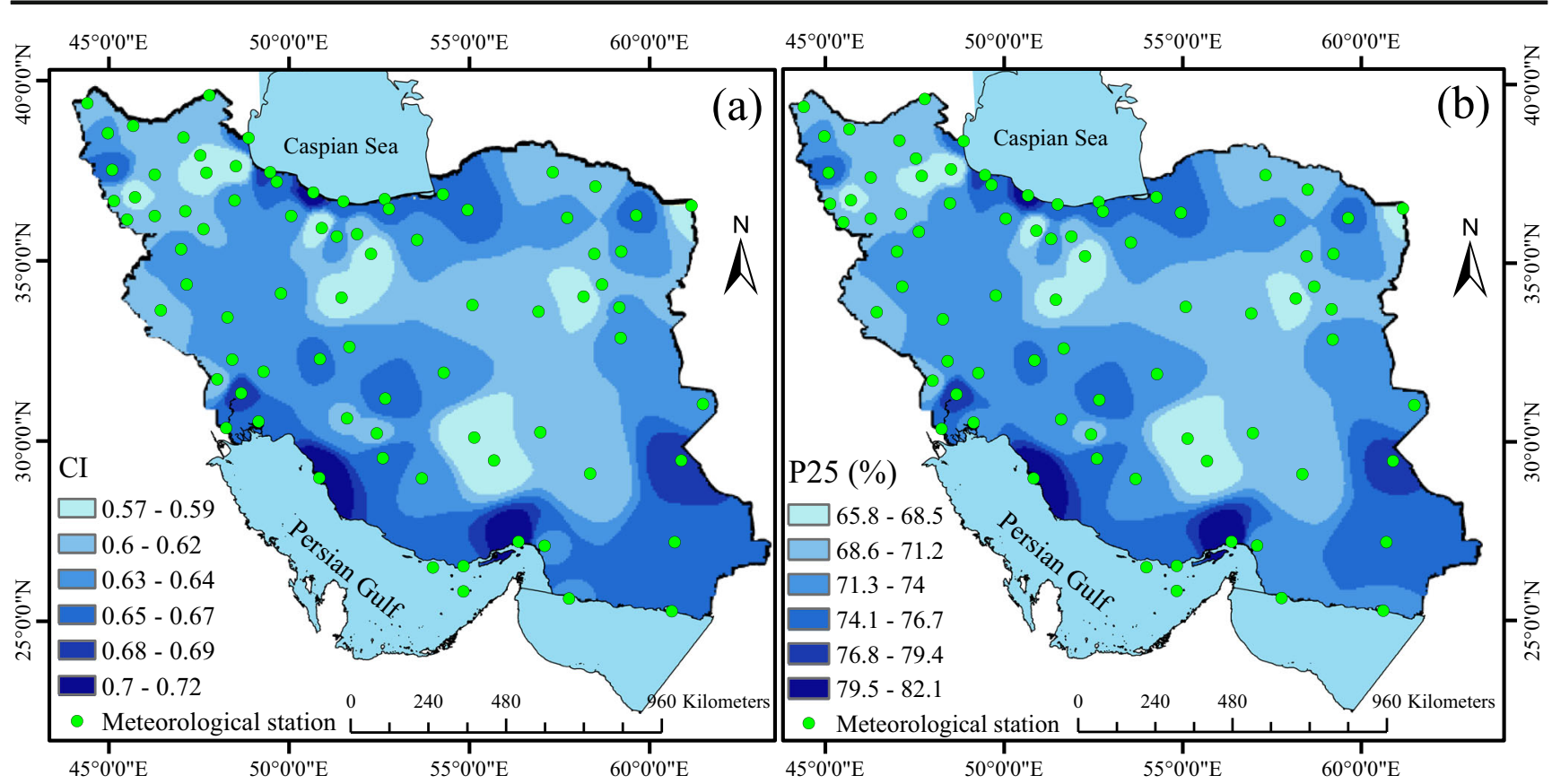

Fig. 4 Spatial distribution of the a CI and b P25 over Iran during 1987-2016

the north can reach $2000 \mathrm{~mm}$ in a year, while the southern areas have annual rainfall values of less than $150 \mathrm{~mm}$ (Fig. 2). In western Iran, where the Zagros Mountains are located and yearly precipitation is higher than $150 \mathrm{~mm}$, the DRCI values were higher than 0.63 . Because these mountains have steep slopes, the risk of flash flooding may be high in the region. The DRCI values in eastern areas were also over 0.63 , signifying high rainfall concentrations.

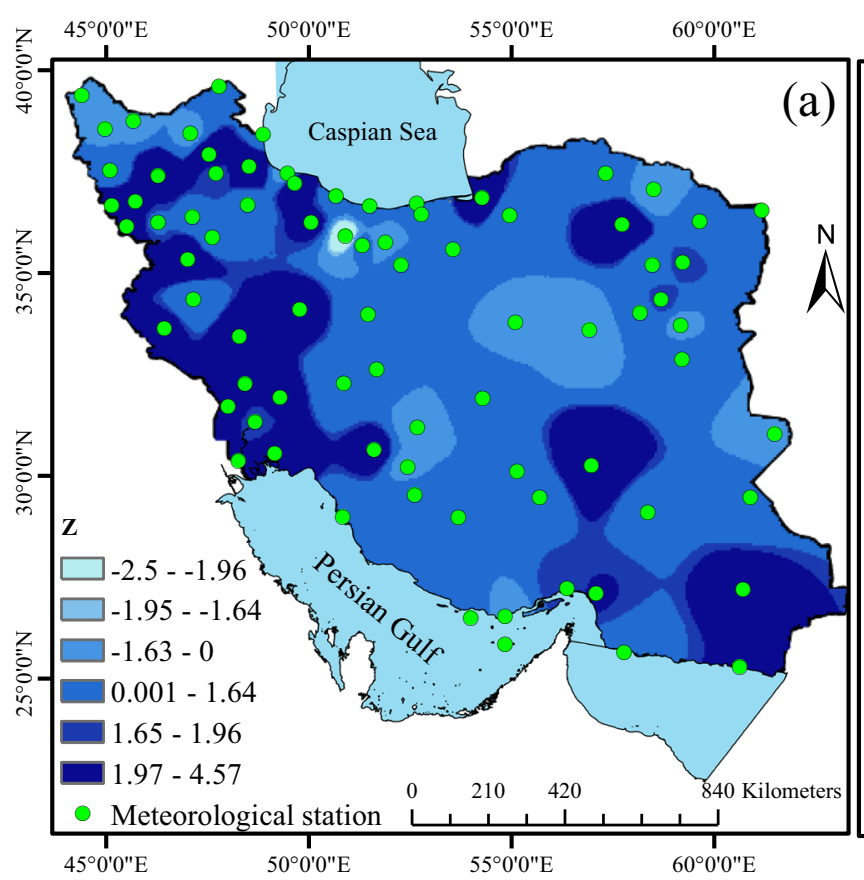

\subsection{Temporal trends in DRCI}

According to the $Z$ values obtained in the MK test, there was an increasing trend in DRCI at 64 of the 80 stations (80\%), and this trend was significant $(\alpha=10 \%)$ at 24 of these 64 stations (37.5\%). The DRCI values showed a decreasing trend at the other 16 stations, but the trend was only significant at one station. These results indicate an overall trend for increasing precipitation concentration in recent decades.

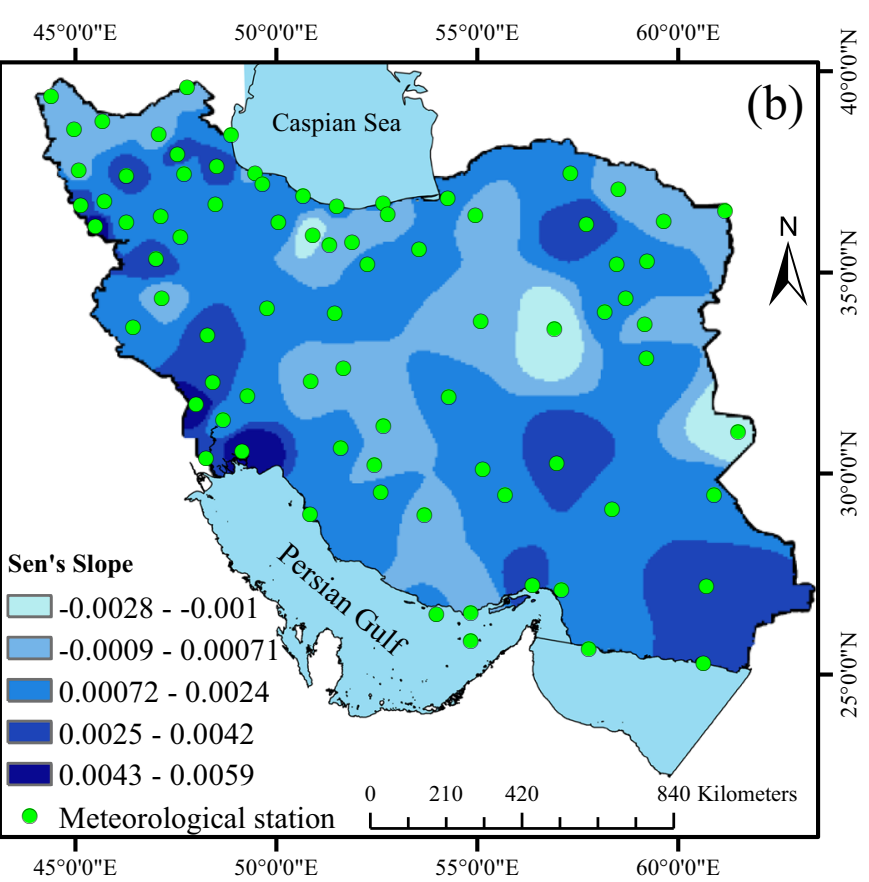

Fig. 5 Spatial distribution of the $\mathbf{a} Z$ and $\mathbf{b}$ Sen Slope estimator in MK test over Iran during 1987-2016 
Fig. 6 Average total rainfall in each month at the 80 stations during the period 1987-2016

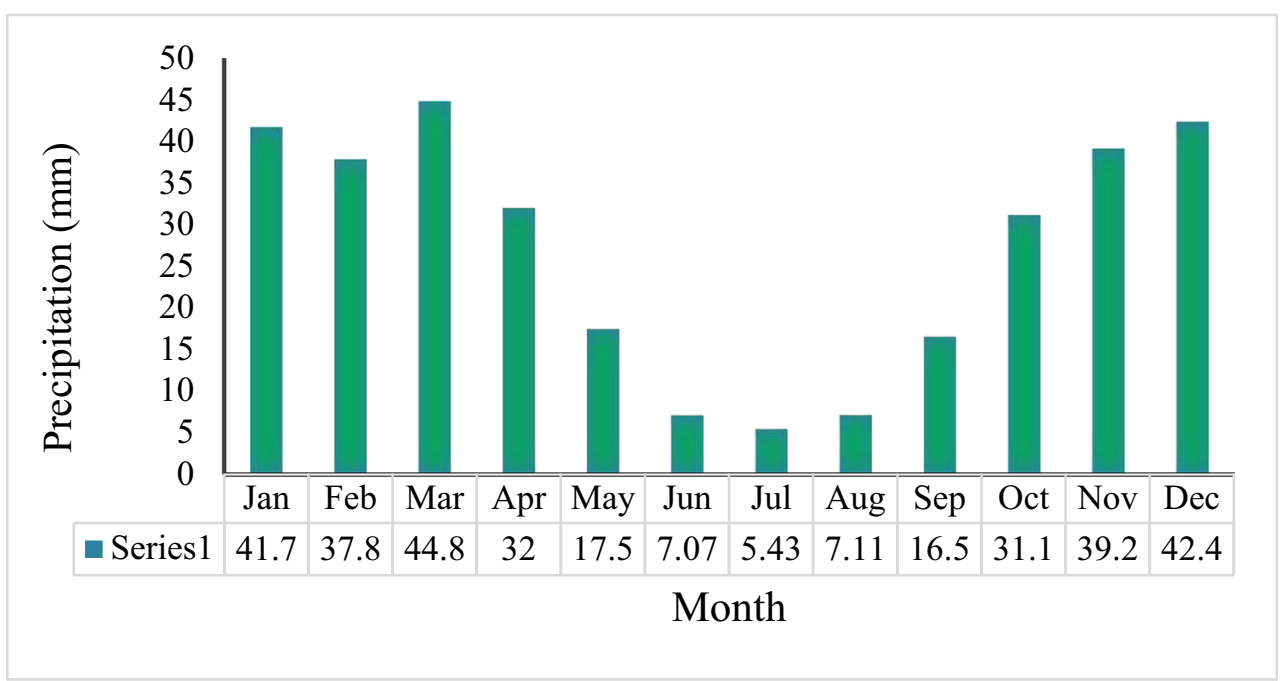

The most significant increasing trends in DRCI were in western and north-western areas of Iran, and in the southeast (Fig. 5a). At some stations in south-west and south-east Iran, DRCI increased by $0.0025-0.0059$ per year, which is equivalent to 0.075 to 0.177 per decade in the past three decades (Fig. 5b). These increases in DRCI values are high, indicating an increasing risk of floods and droughts in these regions. Severe widespread flooding occurred in the west and south-west of Iran in March 2019, resulting in the death of 70 people. In central regions, where the Dasht-e Kavir and Lut Deserts are located, yearly rainfall is low and the DRCI trend in the study period was non-significant.

\subsection{Spatial distribution of MRPI}

The mean monthly rainfall in Iran for every month of the year, based on datasets from the 80 meteorological stations, is illustrated in Fig. 6, while monthly precipitation boxplots are displayed in Fig. 7. Further analysis was limited to the seven rainiest months in the year; i.e., the spatial distribution of
MRPI in only March, December, January, November, February, April, and October was assessed.

The percentage of rainfall falling in each month was very dissimilar in different areas of Iran. The spatial distribution of MRPI for the seven rainiest months is shown in Fig. 8, based on the average values for the 30 -year study period. In January, the highest MRPI (25-32\%) was found in southern regions, while the lowest MRPI (4-11\%) was in northern Iran. In contrast, the highest MRPI in October (16-22\%) was in northern areas. In February and March, MRPI increased from the west of Iran (roughly 4\%) to the east (approximately 24\%). Interestingly, the MRPI values in April declined from $20 \%$ in the north-west to $2-7 \%$ in southern and southeastern regions. In November, narrow areas in the north and south-west of Iran had the highest MRPI values (13$17 \%)$, followed by western parts (9-13\%). South-western Iran had the highest MRPI values in December. These results indicate that MRPI in rainy months differs from the north to the south and from the west to the east, indicating a need for region-specific water resource regulations in different areas of Iran.

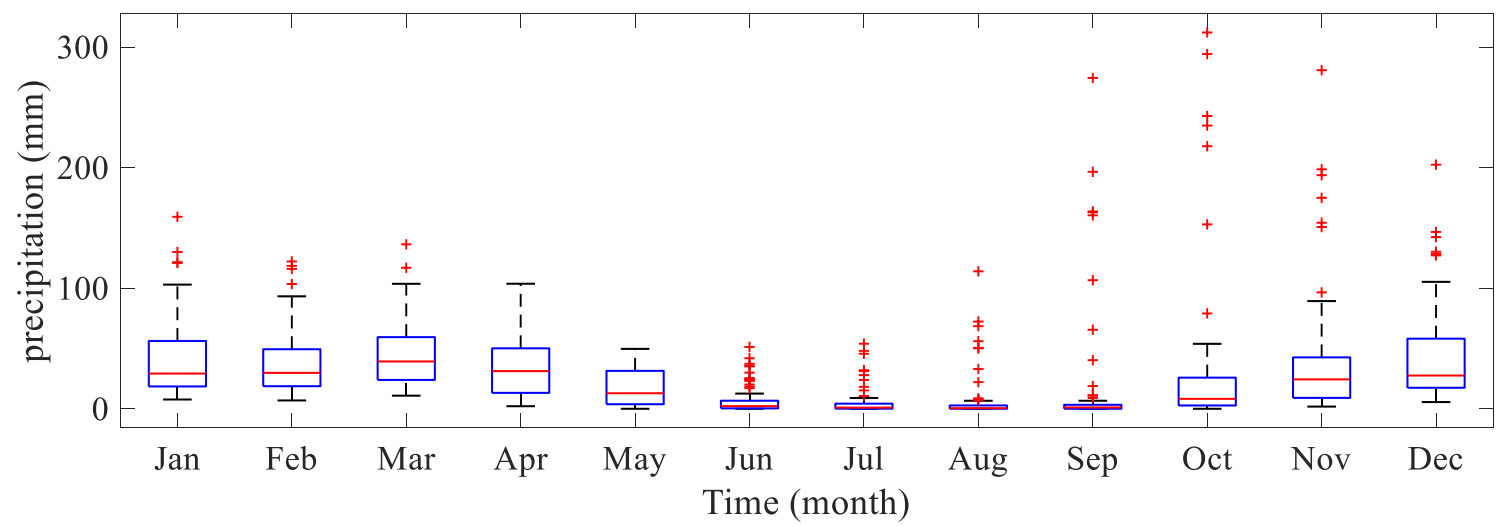

Fig. 7 Boxplot of average total rainfall in each month at the 80 stations during the period 1987-2016 


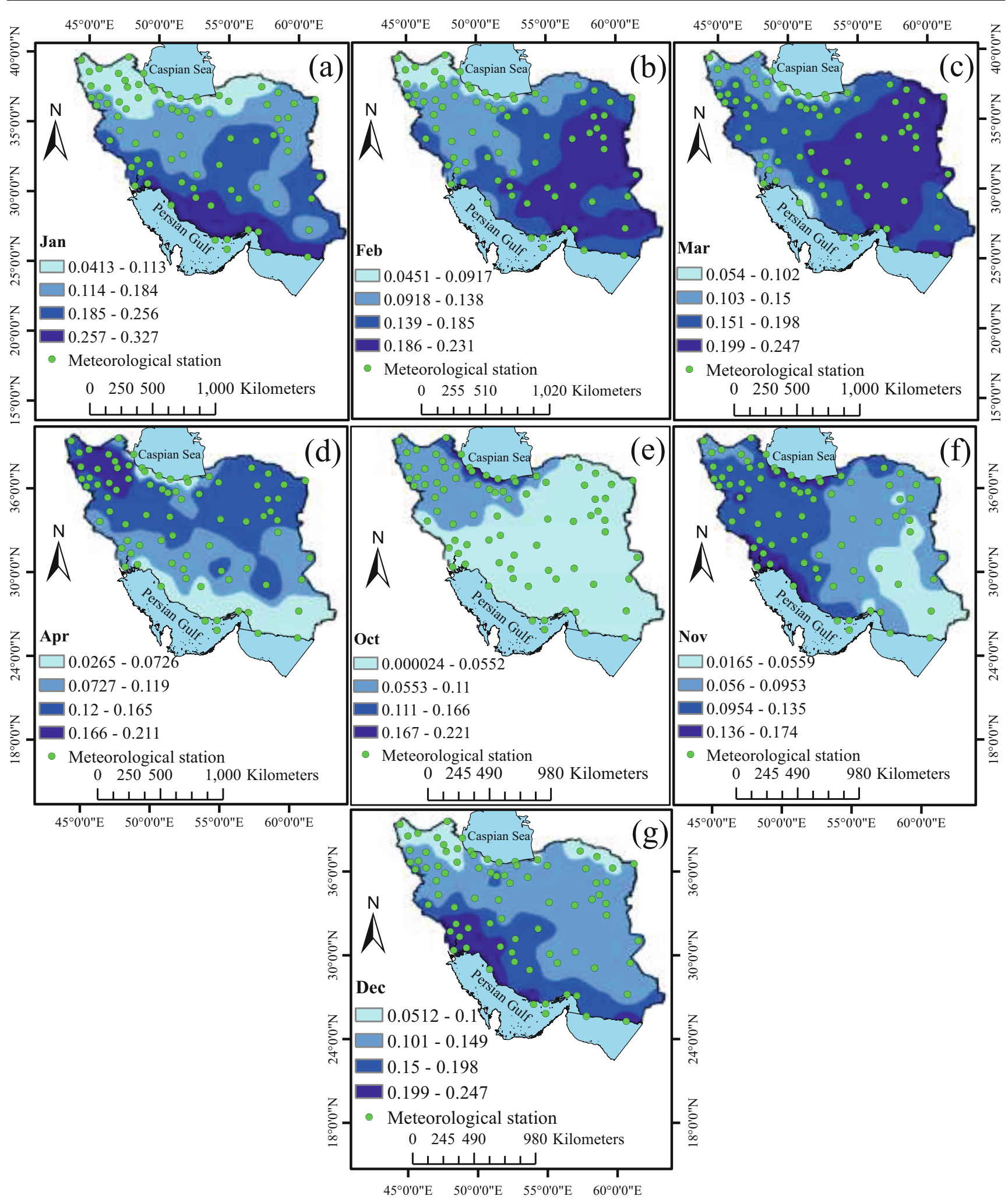

Fig. 8 Spatial distribution of the MRPI in Iran during 1987-2016. a Jan, b Feb, c Mar, d Apr, e Oct, f Nov, and g Dec

\subsection{Temporal trends in MRPI}

The distributions of $Z$ values from MK tests and Theil-Sen slope estimator associated with MRPI in the rainiest months are presented in Fig. 9 and Fig. 10, respectively. Decreasing and increasing trends in MRPI were observed in different regions of Iran, with the trends in February, March, and November being significant at several meteorological stations. 


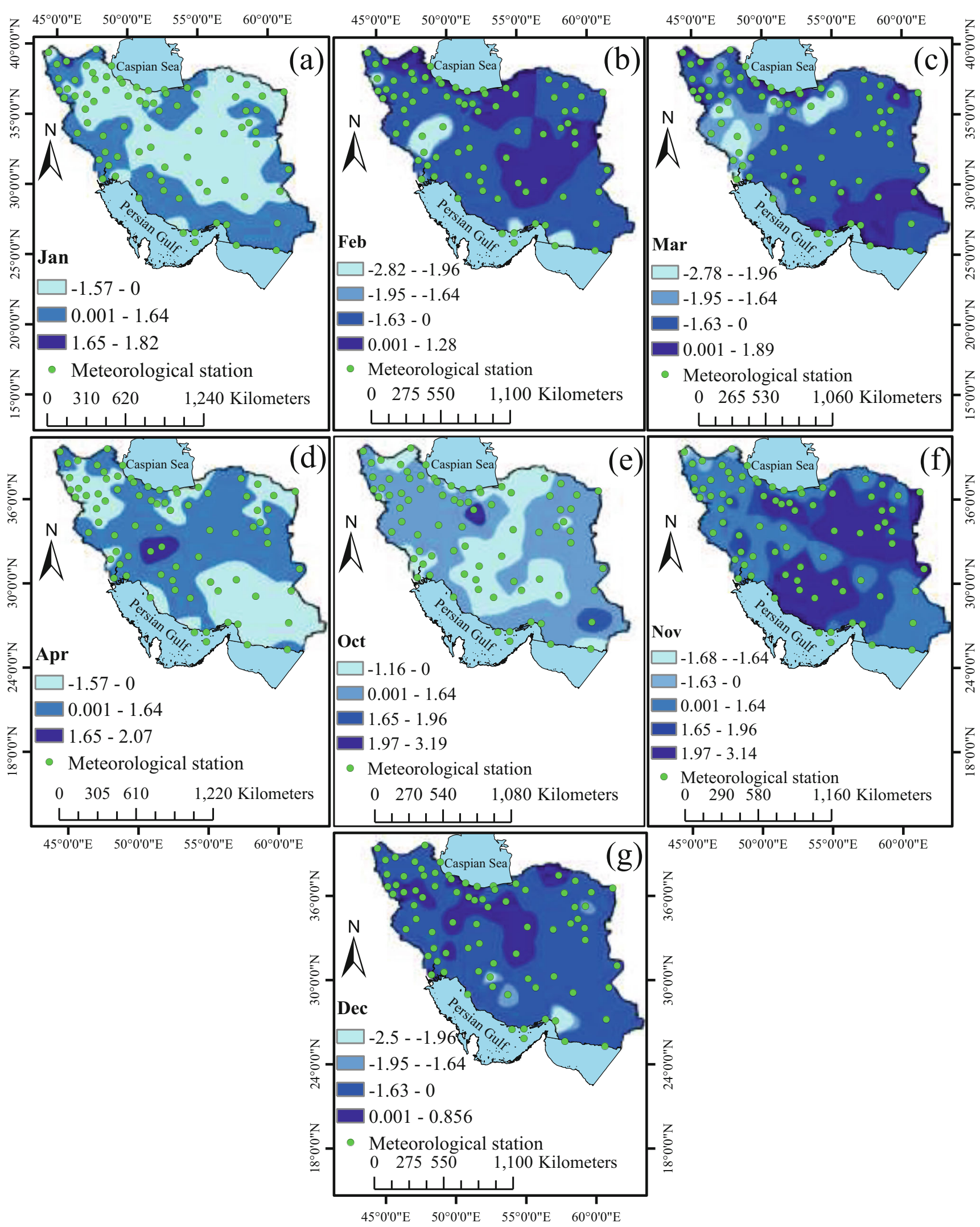

Fig. 9 Spatial distribution of the Z criteria in MK test for RPI in Iran during 1987-2016. a Jan, b Feb, c Mar, d Apr, e Oct, f Nov, and g Dec 


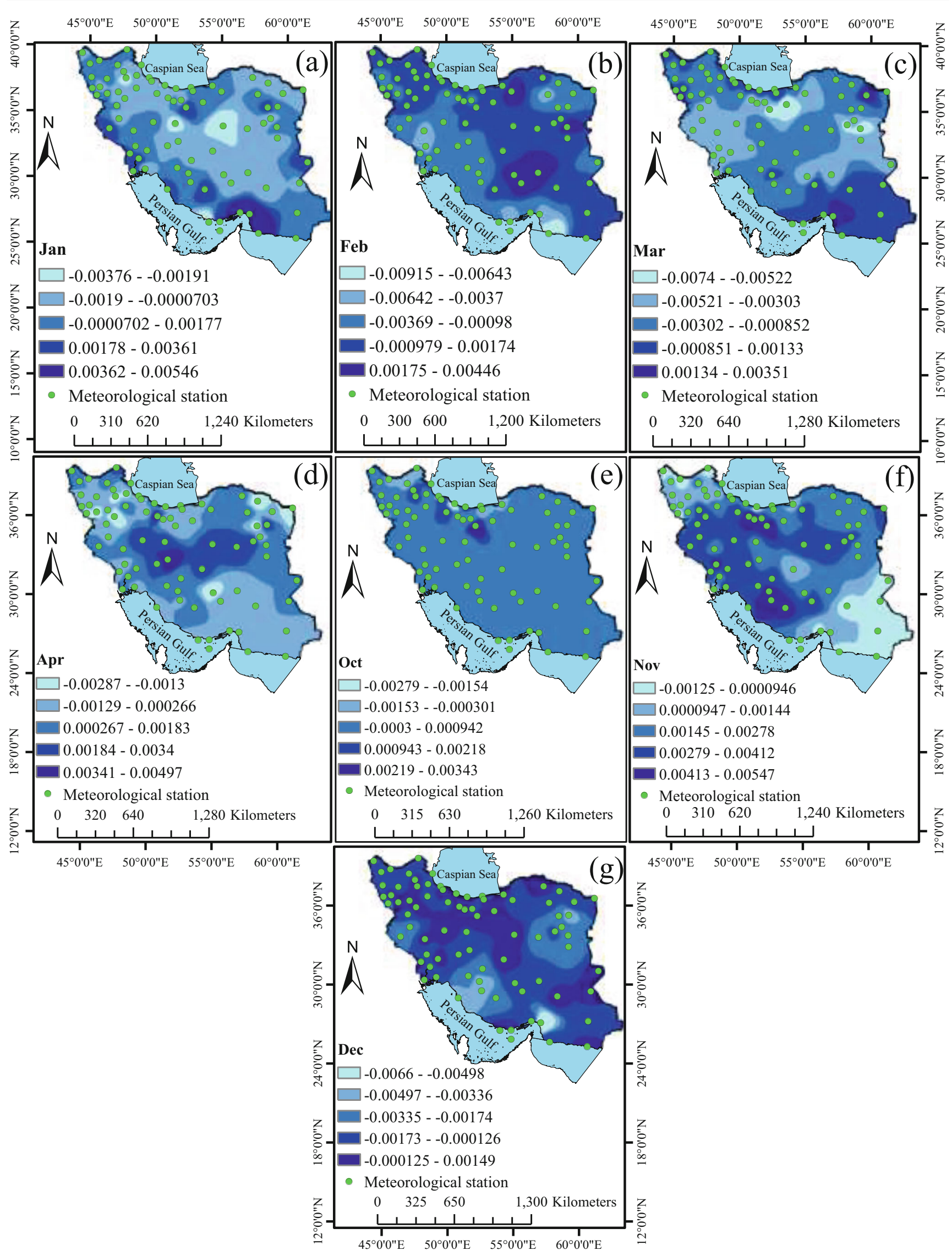

Fig. 10 Spatial distribution of the Sen's slope estimator for RPI in Iran during 1987-2016. a Jan, b Feb, c Mar, d Apr, e Oct, f Nov, and g Dec 
Table 2 Spearman's correlation coefficient between the variables daily rainfall concentration index (DRCI) monthly rainfall percentage index (MRPI) and elevation in the seven rainiest months in Iran

\begin{tabular}{llllllllll}
\hline Parameter & $\begin{array}{l}\text { MRPI- } \\
\text { Jan }\end{array}$ & $\begin{array}{l}\text { MRPI- } \\
\text { Feb }\end{array}$ & $\begin{array}{l}\text { MRPI- } \\
\text { Mar }\end{array}$ & $\begin{array}{l}\text { MRPI- } \\
\text { Apr }\end{array}$ & $\begin{array}{l}\text { MRPI- } \\
\text { Oct }\end{array}$ & $\begin{array}{l}\text { MRPI- } \\
\text { Nov }\end{array}$ & $\begin{array}{l}\text { MRPI- } \\
\text { Dec }\end{array}$ & Elevation & CI \\
\hline Elevation & -0.15 & 0.111 & $0.262^{* * *}$ & $0.591^{* * *}$ & 0.015 & -0.178 & -0.131 & 1 \\
DRCI & $0.186^{*}$ & 0.067 & $-0.253^{* * *}$ & $-0.592^{* * *}$ & 0.009 & $0.24^{* *}$ & $0.322^{* * *}$ & $-0.469^{* * *}$ & 1 \\
\hline
\end{tabular}

$*$ Refers to the significance at $95 \%$ level

***efers to the significance at $99 \%$ level

$* * *$ Refers to the significance at $999 \%$ level

In January, non-significant upward trends in MRPI were mainly seen in southern and south-western regions, while central parts of Iran showed non-significant downward trends. Although the trends in the south were not statistically significant, MRPI increased by approximately $0.2-0.5 \%$ per year (Fig. 10a). Compared with the average value $(20-30 \%)$ of MRPI in those areas, this change is considerable.

In February, the majority of meteorological stations in Iran showed a declining tendency in MRPI, with the decreasing trends being significant $(p<0.10)$ for some stations in the west (see Fig. $9 b)$. As shown in Fig. 10b, MRPI increased by roughly $1-6 \%$ per decade in western areas. However, MRPI in February showed a non-significant declining tendency at some stations in the northern and central zones.

Most areas of Iran displayed a decreasing trend in MRPI in March, and this trend was significant $(p<10)$ at several stations in the west and north (see Fig. 9c). According to the Theil-Sen estimator, a decline in MRPI of 3-7\% per decade has occurred at these stations. Since the average value of MRPI at these stations ranged between 10 and $15 \%$, the estimated drop in MRPI was quite sizeable, representing a considerable change in MRPI. A decline of 3-7\% per decade was also observed at several western stations, but the average MRPI values at those stations were around 20-25\%.

In April and October, both upward and downward trends for MRPI were observed in Iran and these trends were nonsignificant (Fig. 9d, e). In April, the greatest increase in MRPI (2-5\% per decade) was found at some stations in the central region. The highest increase in MRPI in October (1-3\% per decade) was found for a few stations in the north. In November, considerable areas in the east and south of Iran showed significant increasing trends in MRPI, with the value increasing by about $2-5 \%$ per decade in those regions ((Fig. $10 \mathrm{f})$. It is worth noting that these regions receive $5-10 \%$ of their annual rainfall in November (Fig. 8f). Consequently, the changes of $2-5 \%$ in MRPI indicate considerable alterations. The MRPI values in December showed a declining tendency in most of Iran. These changes were not significant $(p>0.10)$, but MRPI dropped by $2-6 \%$ per decade at many stations throughout Iran.

\subsection{Spearman correlation analysis}

Spearman's correlation coefficient values between DRCI and MRPI in the seven most rainy months and station elevation are reported in Table 2. The correlation between DRCI and station elevation was about -0.47 , indicating a moderate inverse correlation. In other words, DRCI decreases as station altitude increases, or the number of rainy days increases at a higher elevation. The MRCI values in April showed the highest positive correlation with station elevation and the highest negative correlation with DRCI. Indeed, DRCI was mainly affected by the rainfall percentage in March. Moreover, there was a direct relationship between MRPI and DRCI for January, November, and December $(r=0.18,0.24$, and 0.32 , respectively). However, the relationships between DRCI and MRPI in March and April were negative (Table 2).

\section{Conclusions}

Spatial and temporal changes in DRCI and MRPI in Iran were studied using precipitation records from 80 stations throughout Iran. The results for DRCI revealed dissimilar patterns in different areas of Iran. The DRCI values ranged from 0.57 to 0.72 and the value was greater than 0.61 at most stations $(60 /$ 80 stations), indicating the contribution of a few rainy days to annual rainfall in Iran. There were increasing trends in yearly DRCI values at many meteorological stations, and these trends were significant for some areas in the west, south-west, and south-east of Iran, indicating a higher likelihood of floods in these regions.

The analysis of monthly rainfall data indicated that MRPI in rainy months depends on the geographical location. In January, southern areas had the highest MRPI (25-32\%) and northern areas the lowest (4-11\%). The highest MRPI in October was in the northern areas (16-22\%).

Trend analysis indicated upward or downward trends for MRPI in many areas of Iran in every month, with changes of $2-7 \%$ per decade at several meteorological stations in some months. The highest significant increasing trend in MRPI (2$5 \%$ per decade) occurred in November, at stations in the east 
and south of Iran. The highest significant decreasing trend in MRPI (3-7\% per decade) occurred in March in western Iran. Spearman correlation analysis showed that MRCI in March had the strongest correlation with DRCI.

Acknowledgements We would like to thank the Iran Meteorological Organization for permission to use the daily precipitation records.

Author contribution SK supplied the acquisition of data; SK, AAH, ATH, and HD provided the conception and design of the study, analysis, and interpretation of data; AAH, ATH, and H.D drafting of the manuscript; SK, ATH, and HD helped to reply the critical comments by the reviewers in the study and edited the manuscript and improved the manuscript as much as before their contributions; S.K, H.D, and ATH revised it critically for important intellectual content, and final approval of the version to be submitted.

Funding Open access funding provided by University of Oulu including Oulu University Hospital.

\section{Declarations}

Conflict of interest The authors declare that no competing interests.

Open Access This article is licensed under a Creative Commons Attribution 4.0 International License, which permits use, sharing, adaptation, distribution and reproduction in any medium or format, as long as you give appropriate credit to the original author(s) and the source, provide a link to the Creative Commons licence, and indicate if changes were made. The images or other third party material in this article are included in the article's Creative Commons licence, unless indicated otherwise in a credit line to the material. If material is not included in the article's Creative Commons licence and your intended use is not permitted by statutory regulation or exceeds the permitted use, you will need to obtain permission directly from the copyright holder. To view a copy of this licence, visit http://creativecommons.org/licenses/by/4.0/.

\section{References}

Abou Zaki N, Torabi Haghighi A, Rossi PM, Xenarios S, Kløve B (2018) An index-based approach to assess the water availability for irrigated agriculture in sub-Saharan Africa. Water 10(7):896

Ahn KH, Palmer RN (2016) Use of a nonstationary copula to predict future bivariate low flow frequency in the Connecticut river basin. Hydrol Process 30:3518-3532

Akbari M, Torabi Haghighi A, Aghayi MM, Javadian M, Tajrishy M, Kløve B (2019) Assimilation of satellite-based data for hydrological mapping of precipitation and direct runoff coefficient for the Lake Urmia Basin in Iran. Water 11:1624

Alavinia M, Saleh FN, Asadi H (2019) Effects of rainfall patterns on runoff and rainfall-induced erosion. Int J Sediment Res 34:270-278

Alijani B, O'brien J, Yarnal B (2008) Spatial analysis of precipitation intensity and concentration in Iran. Theor Appl Climatol 94:107124

Alijanian M, Rakhshandehroo GR, Mishra A, Dehghani M (2019) Evaluation of remotely sensed precipitation estimates using PERSIANN-CDR and MSWEP for spatio-temporal drought assessment over Iran. J Hydrol 579:124189
Bahrami M, Bazrkar S, Zarei AR (2019) Modeling, prediction and trend assessment of drought in Iran using standardized precipitation index. J Water Clim Change 10:181-196

Benhamrouche A, Boucherf D, Hamadache R, Bendahmane L, Martín Vide J, Teixeira Nery J (2015) Spatial distribution of the daily precipitation concentration index in Algeria. Nat Hazards Earth Syst Sci 15(3):617-625

Caloiero T, Coscarelli R, Pellicone G (2020) A gridded database for the spatiotemporal analysis of rainfall in Southern Italy (Calabria Region). In: Environmental Sciences Proceedings, vol 1. Multidisciplinary Digital Publishing Institute, $\mathrm{p} 6$

Chen F-W, Liu C-W (2012) Estimation of the spatial rainfall distribution using inverse distance weighting (IDW) in the middle of Taiwan. Paddy Water Environ 10:209-222

Cochrane L, Lewis SC, Engdaw MM, Thornton A, Welbourne DJ (2020) Using farmer-based metrics to analyze the amount, seasonality, variability and spatial patterns of rainfall amidst climate change in southern Ethiopia. J Arid Environ 175:104084

Darand M, Khandu K (2020) Statistical evaluation of gridded precipitation datasets using rain gauge observations over Iran. J Arid Environ 178:104172

Datta P, Das S (2019) Analysis of long-term precipitation changes in West Bengal, India: an approach to detect monotonic trends influenced by autocorrelations. Dyn Atmos Oceans 88:101118

Deng S, Chen T, Yang N, Qu L, Li M, Chen D (2018) Spatial and temporal distribution of rainfall and drought characteristics across the Pearl River basin. Sci Total Environ 619:28-41

Espinoza PAS, Martín-Vide J (2014) Spatial analysis of rainfall daily trends and concentration in Chile. Investigaciones Geográficas:ág. 53-66

Fadhel S, Rico-Ramirez MA, Han D (2018) Sensitivity of peak flow to the change of rainfall temporal pattern due to warmer climate. J Hydrol 560:546-559

Güçlü YS (2020) Improved visualization for trend analysis by comparing with classical Mann-Kendall test and ITA. J Hydrol 584:124674

Haghighi AT, Darabi H, Shahedi K, Solaimani K, Kløve B (2020) A scenario-based approach for assessing the hydrological impacts of land use and climate change in the Marboreh Watershed, Iran. Environ Model Assess 25(1):41-57

Hamed KH (2008) Trend detection in hydrologic data: the MannKendall trend test under the scaling hypothesis. J Hydrol 349:350 363

Hekmatzadeh AA, Kaboli S, Haghighi AT (2020) New indices for assessing changes in seasons and in timing characteristics of air temperature. Theor Appl Climatol 1-15

Henry S, Schoumaker B, Beauchemin C (2004) The impact of rainfall on the first out-migration: a multi-level event-history analysis in Burkina Faso. Popul Environ 25:423-460

Javari M (2017) Spatial variability of rainfall trends in Iran. Arab J Geosci $10: 78$

Katiraie-Boroujerdy P-S, Nasrollahi N, K-1 H, Sorooshian S (2013) Evaluation of satellite-based precipitation estimation over Iran. J Arid Environ 97:205-219

Khalili K, Tahoudi MN, Mirabbasi R, Ahmadi F (2016) Investigation of spatial and temporal variability of precipitation in Iran over the last half century. Stoch Env Res Risk A 30:1205-1221

Khavarian-Garmsir AR, Pourahmad A, Hataminejad H, Farhoodi R (2019) Climate change and environmental degradation and the drivers of migration in the context of shrinking cities: a case study of Khuzestan province, Iran. Sustain Cities Soc 47:101480

Llano MP (2018) Spatial distribution of the daily rainfall concentration index in Argentina: comparison with other countries. Theor Appl Climatol 133:997-1007

Martin-Vide J (2004) Spatial distribution of a daily precipitation concentration index in peninsular Spain. Int J Climatol 24:959-971 
Monjo R, Martin-Vide J (2016) Daily precipitation concentration around the world according to several indices. Int J Climatol 36:3828-3838

Moradi M (2020) Trend analysis and variations of sea surface temperature and chlorophyll-a in the Persian Gulf. Mar Pollut Bull 156: 111267

Narayana A (2006) Rainfall variability and its impact on the sediment discharge from the rivers of Kerala Region, Southwestern India. J Geol Soc India 68:549

Noori MJ, Hassan HH, Mustafa YT (2014) Spatial estimation of rainfall distribution and its classification in Duhok governorate using GIS. J Water Resour Prot 2014

Peng Z, Wang Q, Bennett JC, Pokhrel P, Wang Z (2014) Seasonal precipitation forecasts over China using monthly large-scale oceanicatmospheric indices. J Hydrol 519:792-802

Pérez-Gutiérrez JD, Paz JO, Tagert MLM, Sepehrifar M (2020) Impact of rainfall characteristics on the NO3-N concentration in a tailwater recovery ditch. Agric Water Manag 233:106079

Pirnia A, Darabi H, Choubin B, Omidvar E, Onyutha C, Haghighi AT (2019a) Contribution of climatic variability and human activities to stream flow changes in the Haraz River basin, northern Iran. J Hydro Environ Res 25:12-24

Pirnia A, Golshan M, Darabi H, Adamowski J, Rozbeh S (2019b) Using the Mann-Kendall test and double mass curve method to explore stream flow changes in response to climate and human activities. J Water Clim Change 10:725-742

Pulwarty RS, Nurse LA, Trotz UO (2010) Caribbean islands in a changing climate. Environment 52:16-27

Rademacher-Schulz C, Schraven B, Mahama ES (2014) Time matters: shifting seasonal migration in Northern Ghana in response to rainfall variability and food insecurity. Clim Dev 6:46-52

Rahimi M, Fatemi SS (2019) Mean versus extreme precipitation trends in Iran over the period 1960-2017. Pure Appl Geophys 176:37173735

Rahman MS, Islam ARMT (2019) Are precipitation concentration and intensity changing in Bangladesh overtimes? Analysis of the possible causes of changes in precipitation systems. Sci Total Environ 690:370-387

Royé D, Martin-Vide J (2017) Concentration of daily precipitation in the contiguous United States. Atmos Res 196:237-247

Saghebian SM, Sattari MT, Mirabbasi R, Pal M (2014) Ground water quality classification by decision tree method in Ardebil region, Iran. Arab J Geosci 7:4767-4777

Saino N, Rubolini D, Jonzén N, Ergon T, Montemaggiori A, Stenseth NC, Spina F (2007) Temperature and rainfall anomalies in Africa predict timing of spring migration in trans-Saharan migratory birds. Clim Res 35:123-134

Sarricolea P, Meseguer-Ruiz Ó, Serrano-Notivoli R, Soto MV, MartinVide J (2019) Trends of daily precipitation concentration in CentralSouthern Chile. Atmos Res 215:85-98

Sayemuzzaman M, Jha MK (2014) Seasonal and annual precipitation time series trend analysis in North Carolina, United States. Atmos Res 137:183-194
Sen PK (1968) Estimates of the regression coefficient based on Kendall's tau. J Am Stat Assoc 63:1379-1389

Serrano-Notivoli R, Martín-Vide J, Saz MA, Longares LA, Beguería S, Sarricolea P, Meseguer-Ruiz O, de Luis M (2018) Spatio-temporal variability of daily precipitation concentration in Spain based on a high-resolution gridded data set. Int J Climatol 38:e518-e530

Singh V, Qin X (2020) Study of rainfall variabilities in Southeast Asia using long-term gridded rainfall and its substantiation through global climate indices. J Hydrol 585:124320

Singh G, Panda RK, Nair A (2020) Regional scale trend and variability of rainfall pattern over agro-climatic zones in the mid-Mahanadi river basin of eastern India. J Hydro Environ Res 29:5-19

Spekkers M, Kok M, Clemens F, Ten Veldhuis J (2013) A statistical analysis of insurance damage claims related to rainfall extremes. Hydrol Earth Syst Sci 17

Strauch AM, MacKenzie RA, Giardina CP, Bruland GL (2015) Climate driven changes to rainfall and streamflow patterns in a model tropical island hydrological system. J Hydrol 523:160-169

Sun Y-W, Pomeroy C, Q-y L, Xu C-d (2019) Impacts of rainfall and catchment characteristics on bioretention cell performance. Water Sci Eng 12:98-107

Tabari H, Talaee PH (2011) Temporal variability of precipitation over Iran: 1966-2005. J Hydrol 396:313-320

Theil H (1992) A rank-invariant method of linear and polynomial regression analysis. In: Henri Theil's contributions to economics and econometrics. Springer, pp 345-381

Torabi Haghighi A, Abou Zaki N, Rossi PM, Noori R, Hekmatzadeh AA, Saremi H, Kløve B (2020) Unsustainability syndrome-from meteorological to agricultural drought in arid and semi-arid regions. Water 12(3):838

Vyshkvarkova E, Voskresenskaya E, Martin-Vide J (2018) Spatial distribution of the daily precipitation concentration index in Southern Russia. Atmos Res 203:36-43

Xu K, Milliman JD, Xu H (2010) Temporal trend of precipitation and runoff in major Chinese Rivers since 1951. Glob Planet Chang 73: 219-232

Yue S, Hashino M (2003) Temperature trends in Japan: 1900-1996. Theor Appl Climatol 75:15-27

Yue S, Pilon P, Phinney B, Cavadias G (2002) The influence of autocorrelation on the ability to detect trend in hydrological series. Hydrol Process 16:1807-1829

Zhang W-Y, Wei Z-W, Wang B-H, Han X-P (2016) Measuring mixing patterns in complex networks by Spearman rank correlation coefficient. Phys A: Stat Mech Appl 451:440-450

Zhao Q, Liu S, Deng L, Dong S, Yang J, Wang C (2012) The effects of dam construction and precipitation variability on hydrologic alteration in the Lancang River Basin of southwest China. Stoch Env Res Risk A 26:993-1011

Publisher's note Springer Nature remains neutral with regard to jurisdictional claims in published maps and institutional affiliations. 